\title{
Cytotoxic and Gene Expression Research on Kras Gene in Lung Cancer Cell Line of A549 Treated with Tinospora Coridifolia Extract
}

\author{
T. Jayalakshmi, R.Priya, M.Harish
}

\begin{abstract}
There has been global resurgence of interest in herbal drugs in the recent past. Though herbal medicines are effective in the treatment of various ailments very often these drugs are unscientifically exploited or improperly used. Therefore, these herbal drugs deserve detailed studies in the light of modern medicine. In spite of synthetic drugs, herbal drugs have their place in therapy. Their effectiveness, low-cost and comparative freedom from serious toxic effects makes these medicines not only popular but also an acceptable mode of treating diseases even in modern times. Medicinal plants are those plants that are used in treating and preventing specific and human has been using herbs for generations around the world, due to charm needed to cure the disease, many people have come to the conclusion that even chemical drugs their answers may already be sick of these medications may be harmful for health them in the future. Still, the use of plants as a source of medicine is very much important for human beings. Identify medicinal and how to use them is so important.
\end{abstract}

Index Terms:- Degeneration, Drugs, macromolecules, toxicity.

\section{INTRODUCTION}

Normally, normal cells multiply to form new cells and worn out cells are removed in an orderly manner. This is a regulated by process controlled by many enzymes and checkpoints. Cancer is initiated when this controlled process is deregulated and cells in any particular part of the body starts multiplying in an uncontrolled fashion. These cancerous cells are different from normal cells in many ways which includes their growth pattern and cell death mechanism ${ }^{[1]}$. Cancerous cells do not die as they deregulate the normal cell death mechanisms and continuously multiply. These altered cells also gain the ability to invade other tissues and parts of the body to form secondary tumors.

The main reason for alteration of normal cells into cancerous cells is DNA damage. This is because DNA is the genetic material which is responsible for every process

Revised Manuscript Received on July 18, 2019

T. Jayalakshmi, Associate Professor, School of Bio-Engineering, Dept. of Genetic Engineering Bharath Institute of Higher Education and Research, Chennai, Tamil Nadu, India. (e-mail: jayamaniraaja07@gmail.com)

R.Priya, Associate Professor, School of Bio-Engineering, Dept. of Genetic Engineering Bharath Institute of Higher Education and Research, Chennai, Tamil Nadu, India.

M.Harish, Student, Department of Bioinformatics, Bharath Institute of Higher Education and Research, Chennai, Tamil Nadu, India. taking place in cell and every protein catalyzing thatprocess. When a normal cell is considered, if the DNA gets damaged by either physical or chemical agents, various cellular mechanisms repairs the damage; if these mechanisms are unable to repair the damage, the cell undergoes controlled death pathway called as apoptosis. These cells are removed because if the cell divides, these DNA alterations will be continued which can be harmful for the body. ${ }^{[2]}$

tion of cells in lung tissue leading to formation of tumor. Most of the primary lung cancers arise from the epithelial cells. The common symptoms of this disease are coughing (including coughing up blood), weight loss, shortness of breath, and chest pains. ${ }^{[3]}$

The main reason for occurrence of lung cancer is attributed to tobacco exposure which is commonly long term [4]. With tobacco exposure covers almost $80-90 \%$ of lung cancer cases, only $10-15 \%$ occurrence is seen in people who are not exposed to tobacco ${ }^{[5]}$. The other factors responsible for lung cancer include genetic factors, exposure to air pollution, radiations, second hand smoke ${ }^{[6-9] .}$ Lung cancer can be diagnosed with many techniques such as radiographs, CT scans etc. These initial diagnostic techniques are followed by confirmatory tests such as biopsy ${ }^{[10]}$. Treatment options are considered based on stage of the disease, health of the patient.

\section{MATERIALS AND METHODS}

Collection of the Material:

\subsection{Anti-Bacterial Activity:}

- Inoculum Preparation:

- Luria-Bertani Broth

Cell Culture:

1. Neutralization:

2. Splitting or Culturing the Cells 


\section{CYTOTOXIC AND GENE EXPRESSION RESEARCH ON KRAS GENE IN LUNG CANCER CELL LINE OF A549 TREATED WITH TINOSPORA CORIDIFOLIA EXTRACT}

Cell Viability Test:

Composition of Preservation Medium:

Preservation of Cells:

- The cells were splitted with Minimal Essential medium i.e., after trypsinization and addition of medium in to centrifuge tube.

- $\quad$ To provide slow cooling, we have to arrange cotton in a container and wipe it with isopropanol and again cotton, cryovials were kept and again cover with cotton (It should contain Isopropanol so that it will not dry up).

\section{Anti-Cancer Activity:}

Maintenance of Cell Line: The A549, Liver Cancer cell line were purchased from NCCS, Pune and the cells were maintained in DMEM medium supplemented with $10 \%$ FBS and the antibiotics penicillin/streptomycin $\left(0.5 \mathrm{~mL}^{-1}\right)$, in atmosphere of $5 \% \mathrm{CO}_{2} / 95 \%$ air at $37{ }^{\circ} \mathrm{C}$.

\section{RESULTS}

Anti Bacterial Activity:

\begin{tabular}{|c|c|}
\hline Gram Positive Strain & $\begin{array}{c}\text { Staphylococcus } \\
\text { aureus }\end{array}$ \\
\hline Gram Negative Strain & E.coli \\
\hline $\begin{array}{c}\text { Standard Drug for Gram } \\
\text { Positive }\end{array}$ & Norfloxacin \\
\hline $\begin{array}{c}\text { Standard Drug for Gram } \\
\text { Negative }\end{array}$ & Ciprofloxacin \\
\hline
\end{tabular}

Gram Positive \&Gram Negative:

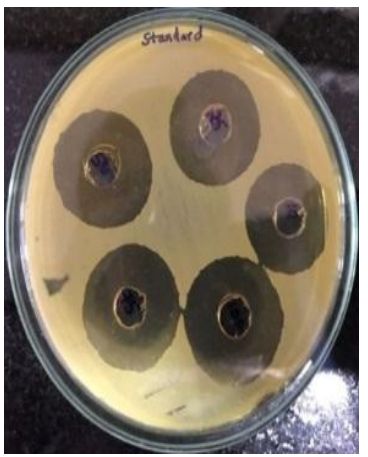

A

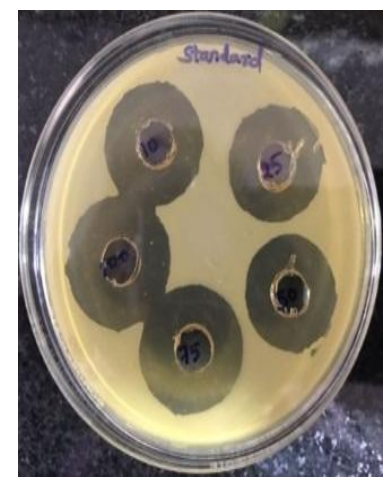

B
Figure 1: Zone of Inhibition shown Anti Bacterial Activity; A: Gram Positive Standard Norfloxacin; B: Gram Negative Standard Ciprofloxacin

\begin{tabular}{|c|c|c|c|c|c|}
\hline \multirow[b]{2}{*}{ Strain } & \multicolumn{5}{|c|}{ Zone of Inhibition(mm) } \\
\hline & $\mu g^{10}$ & $\mu^{25}$ & $\begin{array}{l}{ }_{\mu g}^{50} \\
\end{array}$ & $\mu g^{75}$ & $\mu g^{100}$ \\
\hline $\begin{array}{c}\text { Gram } \\
\text { Positive }\end{array}$ & 9 & 10 & 11 & 14 & 16 \\
\hline $\begin{array}{c}\text { Gram } \\
\text { Negative }\end{array}$ & 10 & 11 & 13 & 15 & 16 \\
\hline
\end{tabular}

Table 1: Zone of Inhibition representing in mm A: Gram Positive Standard Norfloxacin;
GRAM POSITIVE:
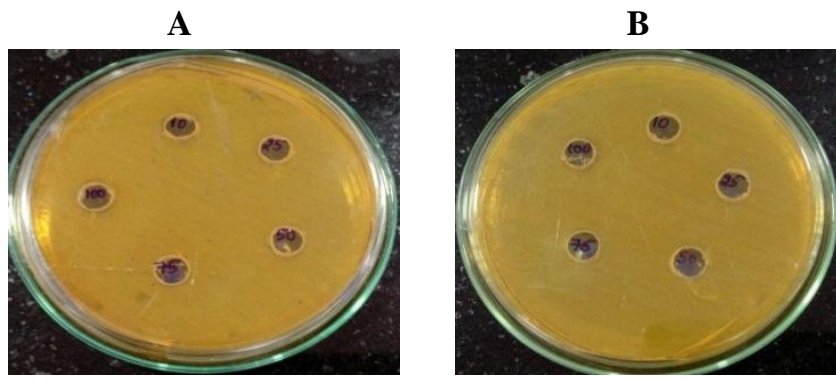

Figure 2: Zone of Inhibition shown in staphylococcus aureus and Bacillus Anti Bacterial Activity in Chloroform Extract

\begin{tabular}{|c|c|c|c|c|c|c|c|}
\hline \multirow{2}{*}{ S.No } & \multirow{2}{*}{ Compound } & & \multicolumn{5}{|c|}{ Zone of Inhibition(mm) } \\
\cline { 3 - 8 } & & $10 \mu \mathrm{g}$ & $25 \mu \mathrm{g}$ & $50 \mu \mathrm{g}$ & $75 \mu \mathrm{g}$ & $100 \mu \mathrm{g}$ \\
\hline 1 & $\begin{array}{c}\text { Chloroform } \\
\text { Extract }\end{array}$ & & - & - & - & - & - \\
\hline 2 & $\begin{array}{c}\text { Chloroform } \\
\text { Extract }\end{array}$ & & - & - & - & - & - \\
\hline
\end{tabular}

Table 2: Zone of Inhibition in $\mathrm{mm}$ shown in staphylococcus aureus and Bacillus Anti BacterialActivity in Chloroform Extract

\section{DISCUSSION:}

Since ancient times medicinal plants have been used as an important source of drugs for curing various diseases. Many plant extracts were used in clinical practice. Pharmacologically active compounds found in plant kingdom, higher plants are arguably the most important groups. Many plants are used with medicinal properties and they cover a broad spectrum of pharmacological effects.

It is especially meaningful in tropical countries due to the great variety of plants belonging to their eco-system. In India many medicinal plants have long been used to treat different kinds of diseases. Today there is an increasing desire to unravel the role of ethno-botanical studies in trapping the centuries old traditional folk knowledge as well as in searching new plant resources of food, drug etc. (Jain, 1987, 1991). People living in the developing countries rely quite effectively on traditional medicine for primary needs (Sullivan and Shealy 1997; Singh, 2002). In this context it is very important to document the ethno-botanical information on medicinal plants before it completely lost.

\section{CONCLUSION:}

The antimicrobial activity was performed for all chloroform and Methanolic extract and ethanolic fraction of Tinosporacordifolia. The antimicrobial screening was done for antibacterial (both gram positive and gram negative microorganism). The antibacterial activity was undertaken out for the disc-plate and cup-plate agar diffusion assay using gram positive and gram negative bacteria. Extracts of Tinosporacordifolia. showed 
a potent activity. The antibacterial activity of Tinosporacordifolia plant extract was found to be higher in hexane extract than methanol extract and Chloroform extract. The plant extract exhibited highest antibacterial activity against Staphylococcus aureus, Bacillus Subtilis and E.Coli, Pseudomonas aeruginosa for $100 \mu \mathrm{g} / \mathrm{ml}$.

A549 and HEK293 Cell lines treated extracts have been subjected to RNA extraction for gene expression analysis. The differential expression study was carried out by using real time RT-PCR method. Diabetes-specific genes of interest (Genetic variants in the gene encoding for KRAS gene have been associated with type 2 diabetes (T2D) and impaired $\beta$ cell function,) are chosen and the expression level of these genes will be examined quantitatively. The expected findings from invitro may reveal the anti-diabetic properties and suggest that the plant extract may be useful for the management of the disease.

\section{REFERENCES:}

1. Defining Cancer". National Cancer Institute. Retrieved 10 June 2014.

2. "Cancer - Signs and symptoms". NHS Choices. Retrieved 10 June 2014.

3. Horn, L; Pao W; Johnson DH (2012). "Chapter 89". In Longo, DL; Kasper, DL; Jameson, JL; Fauci, AS; Hauser, SL; Loscalzo, J. Harrison's Principles of Internal Medicine (18th ed.). McGraw-Hill. ISBN0-07-174889$\underline{X}$.

4. "Lung Carcinoma: Tumors of the Lungs". Merck Manual Professional Edition, Online edition. Retrieved15 August 2007.

5. Thun MJ, Hannan LM, Adams-Campbell LL, et al. (September 2008). "Lung cancer occurrence in neversmokers: an analysis of 13 cohorts and 22 cancer registry studies".

6. $\overline{\text { Alberg }}$ AJ, Samet JM (2010). "Chapter 46".Murray\& Nadel's Textbook of Respiratory Medicine (5th ed.). Saunders Elsevier.

7. O'Reilly, KM; Mclaughlin AM; Beckett WS; Sime PJ (March 2007). Disease". American Family Physician 75 (5): 683-688.

8. Carmona, RH (27 June 2006). "The Health Consequences of Involuntary Exposure to Tobacco Smoke: A Report of the Surgeon General". U.S. Department of Health and Human Services. Secondhand smoke exposure causes disease and premature death in children and adults who do not smoke. Retrieved 201406-16

9. "Tobacco Smoke and Involuntary Smoking" (PDF).IARC Monographs on the Evaluation of Carcinogenic Risks to Humans (WHO International Agency for Research on Cancer) 83. 2004. There is sufficient evidence that involuntary smoking (exposure to secondhand or 'environmental' tobacco smoke) causes lung cancer in humans. ... Involuntary smoking (exposure to secondhand or 'environmental' tobacco smoke) is carcinogenic to humans (Group 1).

10. Lu C, Onn A, Vaporciyan AA, et al. (2010). "78: Cancer of the Lung". Holland-Frei Cancer Medicine (8th ed.). People's Medical Publishing House.

11. Working Group Collaborated with IAP and IASLC Tumours of the lung. In: Travis WD, Brambilla E, Mueller-Hermelink HK, Harris CC, Eds. Tumours of the lung, pleura, thymus and heart. World Health Organization Classification of Tumours. Pathology \& Genetics. Lyon, IARC Press, 2004, 9-124. 